\title{
THE EFFECT OF DIFFERENT POLLINATORS ON FRUIT SET AND SOME FRUIT CHARACTERISTICS IN APPLE
}

\author{
Mehmet Yaman ${ }^{1,}$, Aydın Uzun ${ }^{1}$, Ercan Yildiz ${ }^{1}$, Hasan Pinar ${ }^{1}$ \\ ${ }^{1}$ Erciyes University, Faculty of Agriculture, Department of Horticulture, Kayseri-Turkey
}

Current Trends in

Natural Sciences

\begin{abstract}
Apple is one of the fruit species in which self-incompatibility is seen. For economical apple production, pollination and fertilization are required. In this study, it was aimed to determine effect of different pollinators on the fruit set ratios and some fruit characteristics of some apple varieties and apple genotypes originating from Kyrgyzstan by hybridization breeding method in 2020 year. According to the results, the highest fruit set ratio was obtained with the combination number $54 \times 36$ with $7.37 \%$, while the lowest value was determined with the combination number $54 \times 56$ with $1.88 \%$. Especially the precipitation that occurred during the fruit set time negatively affected the results. In the fruit characteristics results, the combination number $54 \times 36$ gave better results than the other combinations in fruit length and fruit width values. On the other hand, $21 \times$ Elstar combination produced the best result in terms of WSDM (water solid dry matter) value and significant differences occurred between combinations in terms of seed number. Evaluating the obtained findings as a guide especially in the breeding studies to be made on apples and in the new orchards to be established may be beneficial for the producers.
\end{abstract}

Keywords: Apple, fruit set, Kyrgyzstan, pollination

\section{INTRODUCTION}

Apple (Malus communis L.) is widely grown both naturally and economically due to its wide adaptability, richness of species and varieties in the World. The homeland regions of the apple are considered as East Asia, Central Asia, West Asia-Europe and North America (Uzun et al., 2019). These regions also include Kyrgyzstan and Turkey, which have a lot of species and varieties in nature. Malus sieversii (Ledeb.) is a species of wild apple and is found in the mountainous regions of Kyrgyzstan (Yan et al., 2008; Volk et al., 2009).

As in many fruit species such as apple, there is a relationship between yield and fruit set. Most of the apple varieties have a self-incompatibility mechanism and this prevents fertilization, which is among the basic stages in fruit setting (Nettancourt, 2001; Broothaerts, 2003; Liu et al., 2018). As a result of the incompatibility caused by the fact that the varieties are in the same allele structures, disruptions occur in the fertilization event. When an orchard is established with a single variety or varieties have the same s allele, there are disruptions in harvesting and economic losses (Schneider et al. 2001; Garratt, 2014; Shogo et al., 2018).

As a result of the incompatibility, pollinator variety is needed in order to get efficiency. The pollinator variety not only affects the attitude of the fruit, but also has effects on the quality of the fruit. In different species such as tangerines (Citrus reticulata L.) (Y1ld1z and Kaplankıran, 2017), 
cherry (Prunus avium L.) (Cirtlik and Beyhan, 2012) and apricot (Prunus armeniaca L.) (Yaman and Uzun, 2020), the effect of pollinator variety on fruit quality has been investigated.

In this study, it was aimed to determine the effect of different pollinators on fruit set and some fruit characteristics in some standard apple varieties and apple genotypes of Kyrgyzstan origin.

\section{MATERIALS AND METHODS}

The study was carried out in 2020 year by using some apple genotypes and standard varieties originating from Kyrgyzstan in the Apple Genetic Resources Collection Parcel of Erciyes University Faculty of Agriculture, Department of Horticulture. Plants in the study material are 5-6 years old and grafted on M111 rootstock. Routine cultural practices (irrigation, soil tillage, pruning) were performed accordingly.

In Kayseri province, where the study was carried out, the terrestrial climatic conditions prevailing in the Central Anatolia Region are seen. Meteorological data of the region, which are especially effective in fruit setting, are given in Table 1. When these values are examined, it is seen that the precipitation that occurs especially during the fruit set times has a negative effect on the fruit set.

Table 1. Some meteorological data of Kayseri region in 2020 year

\begin{tabular}{|cllllll|}
\hline Year & Month & $\begin{array}{l}\text { Max. } \\
\text { temperature } \\
\left({ }^{\circ} \mathrm{C}\right)\end{array}$ & $\begin{array}{l}\text { Min. } \\
\text { temperature } \\
\left({ }^{\circ} \mathrm{C}\right)\end{array}$ & $\begin{array}{l}\text { Average relative } \\
\text { humidity } \\
(\%)\end{array}$ & $\begin{array}{l}\text { Wind } \\
\text { speed } \\
\left(\mathrm{m}^{-5}\right)\end{array}$ & $\begin{array}{l}\text { Average } \\
\text { temperature } \\
\left({ }^{\circ} \mathrm{C}\right)\end{array}$ \\
\hline \multirow{2}{*}{$\mathbf{2 0 2 0}$} & March & 23.0 & -5.3 & 65.4 & 1.7 & 7.0 \\
\cline { 2 - 7 } & April & 24.8 & -2.6 & 60.1 & 1.5 & 10.2 \\
\cline { 2 - 7 } & June & 33.3 & 1.8 & 57.0 & 1.8 & 15.5 \\
\cline { 2 - 7 } & July & 33.9 & 5.4 & 54.5 & 1.5 & 19.3 \\
\hline
\end{tabular}

\section{Determination of Fruit Set Ratios}

Pollens of selected cultivars were gathered from non-burst flower buds at balloon stage and pollens were rubbed onto emasculated flowers with the aid of a watercolor paint brush and hybridization procedures were performed accordingly (Yaman and Uzun, 2020). Hybridization was made on a different number of flowers for each hybridization combination. Fruit set rates were determined by dividing the harvested fruits by the number of pollinated flowers and multiplying the obtained results by 100 .

\section{Determination of Fruit Characteristics}

Some parameters such as fruit length, fruit width, WSDM (water solid dry matter) and seed number were investigated in the fruits in which fruit set was observed after the hybridization process. Experimental data were subjected to statistical analyses with the aid of software SPSS 15.0 (IBM Company, USA) and significant means were compared with Duncan's multiple range test at $P<.05$ significance level and the values of the varieties are presented as mean \pm standard deviation (SD).

\section{RESULTS AND DISCUSSIONS \\ Fruit Set Ratios}

In apple hybridization studies, pollination was performed on different numbers of flowers ranging from $95(54 \times 36)$ to $210(56 \times$ Box $)$ for each combination. As a result of these processes, fruit setting numbers varying between $3(54 \times 56,56 \times$ Elstar $)$ and $9(56 \times$ Chest $)$ were determined in 
combinations. Depending on the number of fruit setting, fruit set rates were determined as the lowest $1.88 \%(54 \times 56)$ and the highest $7.37 \%(54 \times 36)($ Table 2$)$.

Table 2. Fruit set ratios of the combinations

\begin{tabular}{|lccc|}
\hline $\begin{array}{l}\text { Hybrid } \\
\text { combination }\end{array}$ & $\begin{array}{c}\text { Number of } \\
\text { pollinated } \\
\text { flowers }\end{array}$ & $\begin{array}{c}\text { Number of } \\
\text { fruit sets }\end{array}$ & $\begin{array}{c}\text { Fruit set } \\
\text { ratio (\%) }\end{array}$ \\
\hline $56 \times$ Sand1k & 210 & 9 & 4.29 \\
$54 \times 55$ & 120 & 6 & 5.00 \\
$58 \times 56$ & 150 & 6 & 4.00 \\
Golden $\times 32$ & 200 & 5 & 2.50 \\
G. Smith $\times 56$ & 100 & 6 & 6.00 \\
$54 \times 36$ & 95 & 7 & 7.37 \\
$63 \times 41$ & 140 & 5 & 3.57 \\
$54 \times 56$ & 160 & 3 & 1.88 \\
$51 \times$ Amasya & 150 & 5 & 3.33 \\
$56 \times$ Elstar & 140 & 3 & 2.14 \\
$56 \times 36$ & 100 & 5 & 5.00 \\
\hline Mean & $\mathbf{1 4 2 . 2 7}$ & $\mathbf{5 . 4 5}$ & $\mathbf{4 . 1 0}$ \\
\hline
\end{tabular}

Pollinators has positive effects on fruit set in apples. In studies conducted by different researchers in apples, it was determined that fruit set values ranged from 10\% to 33\% (Akkurt et al., 2020), and in another study, fruit set values ranged from $4 \%$ to $35 \%$ depending on varieties and pollinators used (Maklad et al., 2020). In addition to the pollinator in the apple, can effect on the fruit set most climatic factors such as precipitation, moisture, etc. In the current study, the precipitations that occurred during pollination and fertilization in Kayseri ecological conditions negatively affected the fruit set and different results were obtained from the studies in the literature.

\section{Some Fruit Characteristics}

In the results obtained to determine the effect of the pollinator variety on fruit quality, statistical differences were observed in all of the parameters examined. The highest result in fruit length values was obtained from the combination numbered $54 \times 36$ with $62.91 \mathrm{~mm}$, and the lowest value was found in the combination numbered $54 \times 55$ with $30.81 \mathrm{~mm}$. The best result in terms of fruit width values is the combination of $54 \times 36$ as in the fruit length and this value is $73.25 \mathrm{~mm}$. WSDM value is an important fruit criterion for apple as in most fruit species. Among the combinations, the highest WSDM value was determined as $56 \times$ Elstar and $56 \times 36$ combinations as $21.00 \%$ and $20.80 \%$, respectively. In the last parameter examined, the number of seeds differed between 13,60 and 1,66 in combinations.

Due to the carpel structure in the apple, there should be a minimum of 5 seeds in order to produce quality fruit (Childers et al., 1995). In a study conducted to determine the pollinator efficiency in Vista bella apple variety, it was determined that the WSDM values varied between $9.99 \%$ and $13.96 \%$ (Akkurt et al., 2020). In another study, it was found that fruit length values varied between $18 \mathrm{~mm}$ and $89.5 \mathrm{~mm}$ in fruits obtained as a result of free pollination of apple species originating from Kyrgyzstan (Uzun et al., 2018). The results of the study were similar to these studies in the 
literature, as well as different results. The reasons for this difference, the different study material, the effects of ecology and hybridization on fruit quality can be shown.

Table 2. Some fruit characteristics in hybrid individuals belonging to different parents

\begin{tabular}{|c|c|c|c|c|}
\hline $\begin{array}{l}\text { Hybrid } \\
\text { combination }\end{array}$ & $\begin{array}{l}\text { Fruit length } \\
(\mathrm{mm})\end{array}$ & $\begin{array}{l}\text { Fruit width } \\
(\mathrm{mm})\end{array}$ & $\begin{array}{c}\text { WSDM } \\
(\%)\end{array}$ & $\begin{array}{c}\text { Number of } \\
\text { seed }\end{array}$ \\
\hline $54 \times 55$ & $30.81 \pm 4.08^{\mathrm{e}}$ & $38.16 \pm 3.82^{\mathrm{d}}$ & $14.86 \pm 1.24^{\mathrm{f}}$ & $1.66 \pm 0.81^{\mathrm{g}}$ \\
\hline $58 \times 56$ & $46.32 \pm 2.26^{\mathrm{bcd}}$ & $54.57 \pm 3.20^{c}$ & $19.33 \pm 1.36^{\mathrm{abc}}$ & $4.00 \pm 1.26^{\mathrm{d}-\mathrm{g}}$ \\
\hline $56 \times$ Sand $1 k$ & $47.53 \pm 4.71^{\mathrm{bcd}}$ & $57.81 \pm 4.28^{c}$ & $20.22 \pm 1.20^{\mathrm{abc}}$ & $6.00 \pm 3.46^{\mathrm{cde}}$ \\
\hline $54 \times 56$ & $49.57 \pm 3.41^{\mathrm{bcd}}$ & $58.31 \pm 2.91^{\mathrm{c}}$ & $18.33 \pm 1.52^{\mathrm{cd}}$ & $3.66 \pm 0.57^{\text {efg }}$ \\
\hline $51 \times$ Amasya & $52.22 \pm 6.64^{\mathrm{b}}$ & $64.61 \pm 7.00^{\mathrm{b}}$ & $19.60 \pm 1.81^{\mathrm{abc}}$ & $13.60 \pm 2.07^{\mathrm{a}}$ \\
\hline $56 \times$ Elstar & $49.78 \pm 0.6^{2}$ & $65.98 \pm 2.67^{b}$ & $21.00 \pm 1.00^{\mathrm{a}}$ & $10.00 \pm 1.00^{\mathrm{b}}$ \\
\hline $56 \times 36$ & $43.27 \pm 3.75^{\mathrm{d}}$ & $55.21 \pm 3.25^{c}$ & $20.80 \pm 0.83^{\mathrm{a}}$ & $8.20 \pm 1.30^{\mathrm{bc}}$ \\
\hline Golden $\times 32$ & $50.13 \pm 3.88^{b c}$ & $58.36 \pm 3.99^{c}$ & $20.66 \pm 1.15^{\mathrm{ab}}$ & $7.00 \pm 1.00^{\mathrm{bcd}}$ \\
\hline G.Smith $\times 56$ & $45.51 \pm 2.16^{\mathrm{cd}}$ & $58.10 \pm 2.37^{c}$ & $18.66 \pm 1.15^{\text {bcd }}$ & $9.33 \pm 1.15^{b}$ \\
\hline $54 \times 36$ & $62.91 \pm 1.24^{\mathrm{a}}$ & $73.25 \pm 3.20^{\mathrm{a}}$ & $16.00 \pm 1.00^{\mathrm{ef}}$ & $2.33 \pm 2.08^{\mathrm{fg}}$ \\
\hline $63 \times 41$ & $46.27 \pm 2.34^{\mathrm{bcd}}$ & $54.29 \pm 1.81^{\mathrm{c}}$ & $17.00 \pm 1.00^{\mathrm{de}}$ & $5.00 \pm 1.73^{\mathrm{def}}$ \\
\hline Mean & $46.54 \pm 8.17$ & $56.75 \pm 9.30$ & $18.86 \pm 2.30$ & $6.30 \pm 3.93$ \\
\hline
\end{tabular}

\section{CONCLUSIONS}

As a result, in this study, it was aimed to determine effect of different pollinators on the fruit set ratios and some fruit characteristics of some apple varieties and apple genotypes originating from Kyrgyzstan by hybridization breeding method in 2020 year. In the apple, where the selfincompatibility mechanism is observed, economic product losses arise due to pollination and fertilization. Even if pollination and fertilization normally occur, there are occasional adverse events in product quality in connection with environmental conditions and annual cultural practises. The results from the current study revealed that the father parent had positive effects, especially in combinations created with the same mother and different father pollinators.

\section{REFERENCES}

Akkurt, E., Mertoğlu, K., Evrenosoğlu, Y. (2020). Vista Bella Elma Çeşidinde Farklı Tozlayıcı Çeşitlerin Meyve Tutumu ve Bazı Meyve Kalite Özellikleri Üzerine Etkisi [The Effect of Different Pollinator Varieties on Fruit Set and Some Fruit Quality Traits in Vista Bella Apple]. ANADOLU Ege Tarımsal Araştırma Enstitüsü Dergisi, 30(2), 284-294.

Broothaerts, W., Janssens, G.A., Proost, P., Broekaert, W.F. (1995). cDNA cloning and molecular analysis of two selfincompatibility alleles from apple. Plant Mol Biol, 27, 499-511.

Cirtlık, B. K., Beyhan, N. (2012). Amasya yöresinde yetiştirilen bazı önemli yerel kiraz çeşitlerinin Ziraat 900 için tozlayıcı olarak kullanılabilirliklerinin araştırılması [Investigation of the usability of some important local cherry varieties grown in Amasya as pollinators for Ziraat 900.]. Anadolu Tar. Bil. Dergisi, 27(2), 64-69.

Fruk, M., Jatoi, M. A., Fruk, G., Vuković, M., Buhin, J., Jemrić, T. (2018). Effect of Timing and Rates of NAA Chemical Thinner on Fruit Quality of apple cv.'Granny Smith'. Agriculturae Conspectus Scientificus, 83(3), 219222.

Garratt, M. P. D., Truslove, C. L., Coston, D. J., Evans, R. L., Moss, E. D., Dodson, C., Potts, S. G. (2014). Pollination deficits in UK apple orchards. Journal of Pollination Ecology, 12(2), 9-14.

Liu, C., Qi, X., Song, L., Li, Y., Li, M. (2018). Species identification, genetic diversity and population structure of sweet cherry commercial cultivars assessed by SSRs and the gametophytic self-incompatibility locus. Scientia Horticulturae, 237, 28-35. 


\section{Current Trends in Natural Sciences}

Vol. 10, Issue 19, pp. 170-174, 2021

https://doi.org/10.47068/ctns.2021.v10i19.022

Current Trends in Natural Sciences (on-line)

ISSN: 2284-953X

Current Trends in Natural Sciences (CD-Rom)

ISSN: 2284-9521

ISSN-L: 2284-9521

ISSN-L: 2284-9521

Maklad, M. F., Anwar, M. I., Awad, N. A. F. (2020). Studies on Compatibility, Fruit Set and Fruit Quality by Different Pollinators in Anna Apple Cultivar. Arab Universities Journal of Agricultural Sciences, 28(2), 537-545.

Nettancourt D, de. (2001) Incompatibility and incongruity in wild and cultivated plants. Springer-Verlag.

Schneider, D., Stern, R. A., Eisikowitch, D., Goldway, M. (2001). Analysis of S-alleles by PCR for determination of compatibility in the Red Delicious apple orchard. J Hortic Sci Biotech 76:596-600.), 547- 557.

Shogo, M., Li, T., Shungo, O., Li, Y. Bai, S. (2018). Efficient breeding and cultivation of type 2 red-fleshed apple cultivars using a search system for suitable apple cultivar combination. Horticultural Plant Journal, 4 (6), 219 225.

Uzun, A., Turgunbaev, K., Abdullaev, A., Pınar, H., Özongun, Ş., Muratbekkızı, A., Badyrıv, M., İlbaş, A.İ., Gürcan, K., Kaymak, K. (2019). Genetic Diversity in Apple Accessions Belong to Different Species Collected from Natural Populations of Tianshan Mountains, South-West Kyrgyzstan, Erwerbs-Obstbau, https://doi.org/10.1007/s10341-019-00441-5.

Volk, G. M., Richards, C. M., Henk, A. D., Reilley, A. A., Miller, D. D., Forsline, P. L. (2009). Novel diversity identified in a wild apple population from the Kyrgyz Republic. HortScience, 44, 516-519.

Yaman, M., Uzun, A. (2020). Evaluation of Superior Hybrid Individuals with Intra and Interspecific Hybridization Breeding in Apricot. International Journal of Fruit Science, 20(sup3), S2045-S2055.

Yan, G.R., Long, H., Song, W.Q., Chen. R.Y. (2008). Genetic polymorphism of Malus sieversii populations in Xinjiang, China. Genet. Resources Crop Evol. 55, 171-181.

Yıldız, E., Kaplankıran. M. (2017). The effect of cross-pollination on fruit set and quality in Robinson and Fremont mandarins. Ege Üniversitesi Ziraat Fakültesi, 54, 107-112. 